\title{
The Power of Women in the Armed Forces
}

\author{
Valbona Medani \\ University of Durrës "Aleksandër Moisiu" \\ angelbona@hotmail.it
}

\section{Doi:10.5901/mjss.2013.v4n10p580}

\begin{abstract}
The aim of this paper is to investigate the various models and the best practices of the participation of women in the armed forces, their influence and integration in a traditionally recognized as a men field. The article examines the main challenges that female military personnel face along the military career and sheds light on the mechanism for the protection and implementation of female rights. Then, it puts forward that the transformation of the armed forces provides a good opportunity to increase the role of women in the armed forces. The paper suggests that based on the experience women have the ability to solve complex, unstable, doubtful and confusing situations related to war. However, this natural endowment should be coupled with operational experience in order to increase their self confidence and their abilities multiplying their power inside the armed forces. Women, with their skills, might offer comparative advantage in the resources needed for the wars of the future. The paper conludes that supporting the gender equality in the armed forces, the involvement of the women in all levels of military decision making and ensuring that they get full and equal rights in the armed forces is key to successful transformation of the armed forces.
\end{abstract}

\section{Introduction}

The aim of this paper is to investigate the various models and the best practices of the participation of women in the armed forces, their influence and integrity, and the challenges they face, highlighting the adequate mechanisms for the protection and implementation of the human rights of women. The overall objective of the paper is the support to the gender equality in the Armed Forces, the full involvement and the true reseprentation of women in all levels of the decision making process.

Eventhough the women had a decisive role in the antiquity the role of women took a sharp curve with the evolution of the history. The character of the woman was seen as very weak, submissive, and biologically constructed to be like that. Her rights were negated leading to conflicts of gender inequality.

\section{Methodology}

The method of research of this paper is qualitative. I make use, mostly, of secondary sources, such as literature in the field. However, I use some primary sources such as military documents and reports in order to gather data and facts on the women's status and position inside the Armed Forces of Albania, on their rights and achievements compared to men.

\section{The most Successful Women in the World and the Novelties associated with them}

Women have fought for their rights for a long time all over the world. However, the first feminist movement, dates at the end of the $18^{\text {th }}$ century. Marie Gouze, lost her life in the struggle to win equal rights for women. She became an example for other women who followed her footprints. Feminist movement, throughout the years, has achieved a broader perception until today. Thanks to this movement the position of women in all aspects of the socciety has been improved intensely. The succsessful engagement of the women brought novielties in many fields. This I would like to say that the power of women and their influence in the social, political, economic life is very important. We might draw the same concluison for the women in Armed Forces as well. Although, less known, the women in the armed forces have struggled for their figure, trying hard to bring change and novelty in life and in the military career. 
1. Margaret Thatcher. She is one of the most famous characters of the world politics, the first Primier Woman of the Great Britain. Thatcher changed the "face" of England introducing reforms in many fields. She made a reputation in the world as the "Iron Lady" because of her strong and decisive character.

2. Angela Merkel. She is the German Chancellor. Actually she is at the top of world's most successful women list. She is famous for her intensive, full of energy engagement in her political career.

3. Hillary Clinton. She became the first female Senator in the US Senate. Hillary Clinton won more primaries and delegates than any other female candidate in American history. She played a role in advocating the creation of the State Children's Health Insurance Program, the Adoption and Safe Families Act, and the Foster Care Independence Act. Clinton was also the first female senator in the US Senate. She ran the Department of State for 4 years under Obama's administration.

4. Boadicea, the British monarc, had an overall control over the country's military forces and demonstrated high military values.

5. Zhan d'Ark was a French woman who led the French armies against the English armies in 15th century.

6. Queen Teuta, was the llirian queen, who led the Illyrian state and the Navy against the much stronger Roman Empire in the 3rd century B.C.

There are a lot of other famous women who have brought important changes in the world.

\section{Contribution of Women in Albanian Armed Forces}

\subsection{Importance}

The adequate role of women in the Armed Forces is a continuous and arguable question in many democracies. Being treated differently, women face discrimination in career. However, it is unquestionable that the access of women in the military is an important aspect of the democratization of the armed forces.

\subsection{It is a question of Non-discrimination}

The participation of women in the military should be a question of non-discrimination, equal chances to have a military career, equal chances to be selected for command duties and negation of anykind of abuse based on gender. This is closely connected with the positive acceptance of the woman in the uniform by the society and her adaption and integration in the military environment creating a new tradition. The participation of women in military might play crucial role in preserving peace which is the mos important mission of militaries today. One of the most important factors that have influenced the increasing role of the women in the military is their cultural value. Women, either individually or collectively have fought for equal rights, in private or public domain, and they have sought to be represented and involved in all professions through political and legal actions. The main reason of exclusion of women from combat roles in the military is the gender differencies which are tied to limitation in physical force, which are believed to impede female personnel to achieve minimal job standarts.

\subsection{Level of participation}

During the last years, the women have started to play a more important role inside the western Armed Forces. However, the absolut number of women in the military remains small and the women are still under-represented compared to their number in the society. The number of females who serve in military differs from country to country. They are more underrepresented in the higher ranks. Women who are already promoted to general or admiral demonstrate that females, too, can have a successful career in the military.

Chart 1. Number of female personnel in the Albanian Armed Forces (AAF)

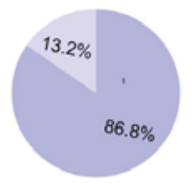


Chart 2. Ranks of female personnel

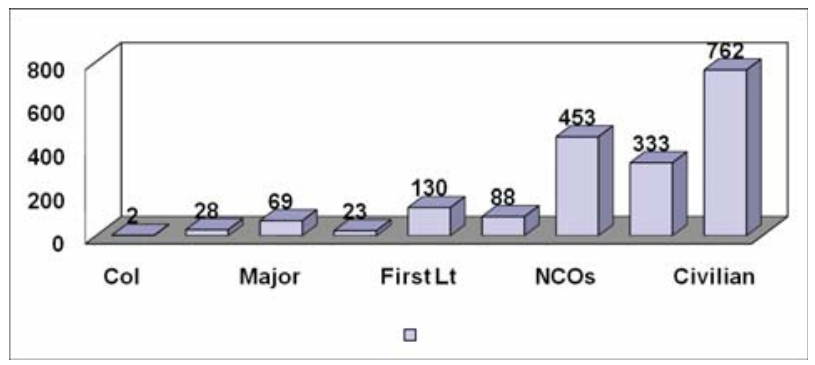

\begin{tabular}{|c|l|c|c|}
\hline $\mathbf{N r}$ & Rank & Females & Percentage \\
\hline 1 & Colonel & 2 & $2.7 \%$ \\
\hline 2 & Lt. Colonel & 28 & $8.25 \%$ \\
\hline 3 & Major & 69 & $11.6 \%$ \\
\hline 4 & Captain & 23 & $6.76 \%$ \\
\hline 5 & $1^{\text {st }}$ Liuetenant & 130 & $19.9 \%$ \\
\hline 6 & $2^{\text {nd }}$ Lieutenant & 88 & $26.4 \%$ \\
\hline & Total & 340 & $14.5 \%$ \\
\hline 7 & NCO & 453 & $12.6 \%$ \\
\hline 8 & Privats & 333 & $9.6 \%$ \\
\hline & Total & 1126 & $13.2 \%$ \\
\hline
\end{tabular}

Participation of females in AAF : Civilian females in the AAF are 762 or $30 \%$

The problem: $95 \%$ of females work in the support sectors and only $5 \%$ work in the operational sectors.

\section{Sexual Harassment and other Forms of Specific Gender Discrimination}

Eventhough males and females are formally equal in most countries; often females do not enjoy the same status as their male collegues in military due to cultural and structural forms of inequality in place. The biggest part of the resistence to females' integration comes from the dominant male culture which views the military in essence as a masculine institution. Discrimination practices includes from prejudiced recruitment and assessment systems, to the absence of separate rooms for females, lack of laws which regulate maternity leaves and denial from combat and operational functions. Differentiated career opportunities explain why females are represented disproportionately in various ranks. Female military personnel should work twice as hard as their male colleagues in order to gain the same respect. In addition, female personnel may be subject of sexual harassment or sexual violence.

\section{Identified Actual Obstacles to the Integration of Females in the Military:}

- First, Functional duties carried by women,

- Second, education and training through out the military career,

- Third, lack of experience in command of operational units

- Fourth, incomplete policies followed by the Ministri of Defense and the General Staff for female education, qualification and assignments in the units of the AAF,

- Fifth, lack of support in the High Commissions of Career,

- Sixth, limited ambitions of the same female personnel for being promoted in rank and duty,

- Finally, their absence in the highest levels of strategic leadership has weaken their image and role in the decision making process. 
Chart 3. Representation of women in militaries of various countries

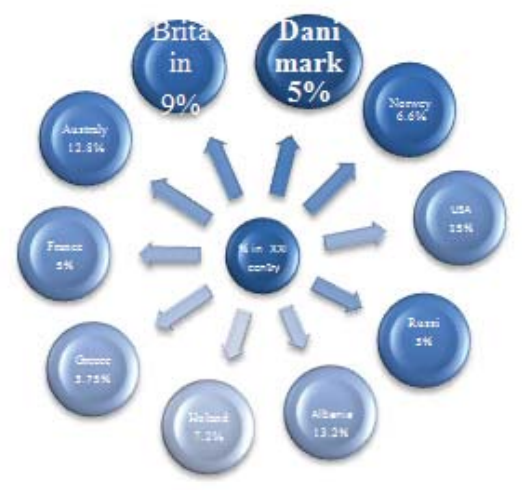

\section{Integration of Military Female Personnel in the Armed Forces of NATO}

The first resolution on women, peace and security, Security Council Resolution 1325 (SCR1325), was unanimously adopted by United Nations Security Council on 31 October 2000. It stressed three main points.

1. Women's equal and full participation as active agents in peace and security,

2. Women's equal and full participation in peace keeping and peace building operations,

3. Protection of women from the disproportionate and unique impact of armed conflict on them.

"NATO is more than merely military power. It is necessary to win hearts and minds. It is impossible to increase the confidence in NATO without the women's contribution."

\section{Establishment of NATO Committee on Women}

The NATO Committe on Women was established as a result of cooperation of NATO nations. In year 1961, a group of old female servicemen from 7 NATO nations met in Kopenhagen and approved a resolution to organize meeting with intervals, in order to discuss the employment and integration of females in the Armed Forces. The military Committe in NATO acknowledged officially the Committee on Women with Document Number 249 dated 19 July 1976. In March 1997, the Military Committee of NATO approved the establishment of the Office of the Committee on the Women in the International Military Staff.

The Committee on Women must advise the NATO's leaders and the representatives of nations on critical issues which influence the female military personnel in achievieng their mission in NATO.

\section{The Committee on Women in AAF}

The Committee on Women in AAF was established on January 4th 2011.

The mission of the committee is to support gender equality in AF, to boost her representation and her role in all levels of decision making, as well as to provide support from all political and military spheres.

Among many tasks of the Committee we may distinguish:

- Support to human rights and liberties according to the principles of the UN Charter resolution and the Security Council Resolution 1325 (SCR1325) on women, peace and security,

- Acceptance of the gender perspective and special assessment of gender issues in order to protect from any kind of violence.

- To advice AAF leadership for critical issues and their ramifications in the AAF

- To encourage the women participating in Peace Support Operations

- To contribute in the protection of women rights

- To provide information on gender issues in all phases of missions of peace support operation.

- Granting equal rights to women and men for promotion, education and qualification, 
- Improvement of Albanian legislation related to ease the procedures of recruitment, education and qualification in the AAF.

\section{Assignment of Females in Combat/ Peace keeping Missions}

Duties: Physician, nurse, Helicopter or Airplane pilot in combat zones, driver, convoy escort, patrol, military police, etc. Military Female Personnel in Peace keeping Operations

They meet the risk in every duty.

The regulation approved in 1994 states that "Women may serve in any field of the peace keeping missions, except in combat battalion in front line, such as land troops, tanks, artillery, special forces etc.

However, it is true that although not considered being in the front line, every day female military servicemen are wounded and killed around the world. The reason is that the combat in these kind of mission does not have front, the risk is imminent everywhere.

\section{Issues with Female Participation in Peace keeping Missions}

Lack of trust is one of the most problematic issues which impede women to achieve the mission. It is thought that females are demoralized, terrorized, stressed and get nervous when exposed to danger.

This biased view has created a wrong opinion that the female soldier is not able to conclude the mission successfully and to help her friends in case of danger. However, facts dismiss this view.

\section{Countries which provide Female Military Personnel to Peace keeping Operations}

US (80 lost their lives in missions), Canada, Great Britain, Ukraine, Australia. Albania has sent 7 females, 4 Officers, 3 NCO, physicians and nurses in the framework of in Afghanistan.

\section{Should female engage in combat roles?}

There are three arguments which support the idea that females should not engage in combat roles:

I. Physical limitation

a. Female military personnel do not have and can't use the same amount of force that their her male enemy might use in close combat.

b. The skeleton system of females is thinner and easier to be injured than that of males..

II. Psycological limitation

a. Lack of confidence in the famales' skills by other soldiers.

b. Fear that female presence might cause disruption.

c. Probability of getting pregnant and leaving the mision

d. Probability that during the mission might be captured, tortured and sexually abused.

III. Tactical limitation

a. In Islamik countries, Islamik militants never surrender to a female.

b. The presence of a female in combat mission has led to lost of control by the team mates who have shown over protective insticts to her.

\section{Theories which advocate for Female Participation in Combat Misisons}

a. Advanced technology used nowdays reduces extremely the physical advantages.

b. Less need for use of force.

c. More tactical and intelligent solutions

The appointment of females should be done based on the experience, training, leading skills and the fulfillment of criteria according to specific tasks and missions. Females consist of half of the population. Not including this big portion of the population means failing to ensure the peace. Females are aware of the risk associated with combat mission and are ready to accept it. Use of females in combat mission may have its own comparative advantage like the case of body search of females of the local population. In addition to that, women have very good communication skills which help establish dialogue with local population and pursue them cooperate instead of rebel. 


\section{Vision for the Future of the Women in the AAF}

The modern technology has a great influence in the conduct of battles. This kind of technology requires talented skillful personnel, male or female.

The women in the military will have a bright future if military leaders would appreciate their contribution in the pas and in the present and would support them to integrate in all structures base don their talent and skills. The must be supported in order to improve their career by advancing their education and taking charge of command positions. The implementation of the lessons learned in the past would help females to achieve their objective and balance the career with personal life.

Technological advancement in armaments and combat systems has lowered the desire of males to serve in Armed Forces. On the contrary, the social evolution of females makes them more suitable to adapt to these changes.

\section{Conclusions and Results of the Study}

Based on the review of the literature and the study of the reports it is concluded that female models in the highest military hierarchy are crucial to assist the future leaders. Females in the military should take advantage of all opportunities to take charge of commad duties so that they can gain the valuable operational experience likewise their male colleagues. They must follow the educational programs and should be encouraged to take greater responsibility.

For the firs time in the Table of Organization of the AAF was added a new column, "gender" which is an organic requirement according to NATO standarts. The ongoing military transformation opens new windows of opportunity for women to broaden their role as an integral part of AAF. Females are an advantangeous human resource for the future wars. They have leadership skills to solve unstable, complex, uncertain and confusing issues related to battles. The combination of education with operational experience will provide females with the adequate tools to be highly appreciated within the transformed military. The paper conludes that supporting the gender equality in the armed forces, the involvement of the women in all levels of military decision making and ensuring that they get full and equal rights in the armed forces is key to successful transformation of the armed forces.

\section{Reccomandations}

The legislation for equal changes should be implemented in military sector as well. The military personale should be recruited based on demonstrated skills and competences avoiding prejudice. The military personnel should be trained on cultural, gender issues as well as appeal procedures. Unit commanders should exercise their authority in order to prevent and punish sexual harassment cases. There should be zero tolerance for sexual harassment and sexual abuse in the military. There should be female counsellors in the Armed Forces. At the same time the armed forces should highlight the benefits that female engament brings to the military. Nonetheless, the state should improve and support the ability of the armed forces to recruit, keep and advance the females in career.

\section{References}

Careiras, H. (2006), Gender and the Military: Women in the Armed Forces of Western Democracies, London: Routledge Anthony Giddens, Simon Griffiths (2007), Sociology, 5th edition, Polity.

OSCE (2011), Udhezues per te drejtat dhe lirite themelore te njeriut personelit te Forcave te Armatosura. Tirane, Cabej. http/:www.echr.coe.int

http:/www.coe.int

http:/www.wikipedia.com

en.wikipedia.org/wiki/Margaret_Thatcher, https://en.wikipedia.org/wiki/Angela_Merkel, https://en.wikipedia.org/wiki/Hillary_Rodham_Clinton, 